\title{
REAKSI PASAR MODAL INDONESIA TERHADAP PERISTIWA PENGUMUMAN HASIL PENGHITUNGAN SUARA PEMILIHAN UMUM DAN PELANTIKAN PRESIDEN AMERIKA SERIKAT
}

\author{
Ni Made Ayu Windika Saraswati ${ }^{1}$ \\ I Ketut Mustanda ${ }^{2}$
}

\author{
${ }^{1,2}$ Fakultas Ekonomi dan Bisnis Universitas Udayana, Bali, Indonesia \\ email: ayu_windika@yahoo.com
}

\begin{abstract}
ABSTRAK
Tujuan penelitian ini adalah untuk menjelaskan reaksi pasar modal Indonesia terhadap peristiwa pengumuman hasil penghitungan suara pemilihan umum dan pelantikan Presiden Amerika Serikat. Penelitian ini menggunakan perusahaan yang terdaftar di indeks LQ45 Bursa Efek Indonesia periode Agustus 2016 sebagai populasi dan metode nonprobability sampling sebagai metode penentuan sampel sehingga diperoleh sebanyak 45 perusahaan. Pengumpulan data dilakukan dengan teknik observasi non partisipan. Pengujian dilakukan dengan pendekatan studi peristiwa dan teknik analisis yang digunakan untuk menguji tingkat signifikansi abnormal return adalah paired sample t-test. Hasil penelitian menunjukkan bahwa (1) Terdapat perbedaan abnormal return sebelum dan setelah peristiwa pengumuman hasil penghitungan suara pemilihan umum Presiden Amerika Serikat dan (2)Terdapat perbedaan abnormal return sebelum dan setelah peristiwa pelantikan Presiden Amerika Serikat. Hal ini berarti bahwa terdapat reaksi pasar di sekitar peristiwa pengumuman hasil penghitungan suara pemilihan umum dan pelantikan Presiden Amerika Serikat.
\end{abstract}

Kata kunci: studi peristiwa, abnormal return, pemilihan umum

\begin{abstract}
This study aims to explain the Indonesian capital market reaction to the announcement of the election vote results and the inauguration of the United States President. The population in this study are companies listed in the index LQ45 Indonesia Stock Exchange period August 2016. Sampling method in this study is nonprobability sampling and total sample are 45 companies. This study uses non-participant observation technique to collect data and event study method with paired t-test analysis techniques to test the significance level of abnormal return. This study finds that (1) there is difference in abnormal return before and after the announcement of the election vote results and (2) there is difference in abnormal return before and after the inauguration of the United States President. The findings indicate that there is market reaction around the announcement of the election vote results and the inauguration of the United States President.
\end{abstract}

Keywords: event study, abnormal return, president election 


\section{PENDAHULUAN}

Pasar modal memiliki peran yang sangat penting bagi perekonomian suatu negara, sebab pasar modal memiliki dua fungsi yang dijalankan sekaligus. Pertama, fungsi ekonomi yang menyatakan bahwa pasar modal sebagai fasilitas yang mempertemukan dua pihak yang berkepentingan, yaitu pihak yang kelebihan dana (investor) dengan pihak yang memerlukan dana (issuer). Kedua, fungsi keuangan yang menyatakan bahwa pasar modal dapat memberikan kesempatan untuk memperoleh imbal hasil bagi investor sesuai dengan karakteristik investasi yang dipilih (Ananto, 2014).

Berinvestasi di pasar modal menjadi sangat menarik karena dapat memperoleh return, namun perlu diperhatikan pula tingkat risiko dari suatu investasi. Ini dikarenakan oleh fluktuasi harga saham yang menandakan dua kemungkinan diantaranya kenaikan harga yang dapat memberikan keuntungan modal (capital gain) atau penurunan harga yang dapat menimbulkan kerugian modal (capital loss). Menghilangkan risiko investasi tidak dapat dilakukan, namun investor dapat menghindari atau mengurangi risiko melalui cara analisis faktor-faktor penyebab risiko dari setiap informasi yang mampu membuat pasar modal bereaksi. Informasi yang dapat mempengaruhi reaksi pasar modal adalah semua informasi yang dianggap penting dan mampu mempengaruhi harga saham, informasi tidak hanya berupa berita yang resmi namun juga isu (Trisnawati dan Diantini, 2013).

Informasi dianggap bermakna bagi investor apabila informasi mampu menggerakkan investor untuk bertransaksi di pasar modal. Terjadinya perubahan 
harga dan volume perdagangan saham mencerminkan adanya aktivitas transaksi di pasar modal (Robert Ang dalam Laksitafresti, 2012). Teori pasar efisien (Efficient Market Hypothesis) membahas hubungan antara informasi dengan harga saham. Menurut Fama (1970) dalam Hartono (2016: 586-590) pasar dikatakan efisien jika pasar bereaksi secara cepat terhadap semua informasi yang relevan. Menurut hipotesis pasar berbentuk setengah kuat, harga sekuritas yang diperoleh di pasar modal secara menyeluruh menunjukkan seluruh informasi yang diumumkan termasuk informasi yang diperoleh dari laporan keuangan perusahaan emiten (Hartono, 2016:586-590). Jika informasi yang diumumkan telah diterima oleh semua pelaku pasar maka pelaku pasar dapat menginterpretasikan dan menganalisis informasi tersebut sebagai good news atau bad news (Ningsih dan Cahyaningdyah, 2014).

Event study (studi peristiwa) merupakan suatu pendekatan untuk melakukan uji tehadap kandungan informasi dari suatu peristiwa. Tujuan pengujian kandungan informasi adalah untuk menguji reaksi pasar terhadap suatu peristiwa. Apabila pasar bereaksi pada waktu informasi tersebut diterima oleh pasar maka dapat dikatakan peristiwa tersebut mengandung informasi yang cukup. Reaksi pasar terjadi jika terdapat perubahan harga dari sekuritas bersangkutan. Reaksi pasar dapat diukur dengan menggunakan return atau abnormal return sebagai nilai perubahan harga saham. Menurut Hartono (2016: 620), abnormal return akan timbul pada peristiwa yang memuat informasi, sebaliknya abnormal return tidak akan timbul pada peristiwa yang tidak memuat informasi. 
Peristiwa yang mengandung informasi sangat mempengaruhi pasar modal yang merupakan salah satu instrumen ekonomi. Semakin tinggi tingkat sensitivitas pasar modal terhadap berbagai peristiwa di sekitarnya, maka pasar modal memiliki peran yang semakin penting dalam perekonomian suatu negara (Suryawijaya dan Setiawan, 1998). Selain peristiwa yang memiliki kandungan informasi, pasar modal dipengaruhi oleh beberapa faktor lain seperti faktor makro, baik yang berasal dari lingkungan ekonomi maupun lingkungan non ekonomi (Nurhaeni, 2009). Fluktuasi harga saham di pasar modal Indonesia tidak hanya dipengaruhi oleh peristiwa yang berasal dari lingkungan ekonomi saja, tetapi juga dapat berasal dari peristiwa dari lingkungan non ekonomi, misalnya saja peristiwa politik.

Peristiwa-peristiwa politik merupakan salah satu bagian dari lingkungan non ekonomi yang dapat mempengaruhi pasar modal yang disebabkan oleh dinamika situasi politik yang pada dasarnya berperan penting terhadap kondisi perekonomian suatu negara. Stabilitas politik yang diikuti dengan stabilitas kondisi ekonomi, cenderung membuat investor merasa aman untuk melakukan investasi di pasar modal. Peristiwa-peristiwa politik dapat memberikan dampak positif maupun negatif terhadap penilaian para investor dan investor potensial.

Diantara semua peristiwa politik, pergantian pemerintahan dengan proses pemilihan umum merupakan peristiwa yang paling mempengaruhi pasar (Hung, 2013). Ini karena kebijakan-kebijakan yang dibuat oleh pemimpin baru nantinya akan mempengaruhi kondisi ekonomi di masa mendatang. Kebijakan pemerintah terkadang memihak dan memudahkan perusahaan atau bahkan sebaliknya, maka 
Ni Made Ayu Windika Saraswati, Reaksi Pasar Modal Indonesia...

sangatlah penting bagi investor untuk memberi perhatian khusus kepada hal tersebut. Oleh karena itu, peristiwa politik seperti rangkaian peristiwa pemilihan presiden Amerika Serikat baik itu peristiwa pengumuman hasil penghitungan suara dan pelantikan presiden merupakan peristiwa yang menarik untuk diteliti. Mengingat bahwa negara adidaya Amerika Serikat merupakan salah satu negara yang melakukan kerjasama dengan Indonesia dalam berbagai bidang khususnya bidang ekonomi, maka rangkaian peristiwa pemilihan presiden di Amerika Serikat merupakan suatu peristiwa penting yang dinilai dapat memberikan dampak yang signifikan terhadap perekonomian Indonesia termasuk pasar modalnya.

Pemilihan presiden pada umumnya merupakan peristiwa yang tidak sulit diduga karena telah ditentukan dan rutin dilakukan setiap lima tahun sekali. Rangkaian peristiwa pemilihan presiden dinilai sebagai peristiwa yang nantinya akan sangat berpengaruh, sehingga penting untuk mengetahui visi dan misi dari masing-masing calon untuk mengetahui bagaimana nantinya kebijakan yang akan dilaksanakan. Setiap kandidat calon presiden memiliki visi, misi dan kebijakan yang dapat mempengaruhi kondisi ekonomi secara global. Situasi tersebut, disinyalir dapat menimbulkan dampak pada kondisi pasar modal Indonesia yang disebabkan oleh aktivitas investasi yang menjadi tidak menentu.

Kandidat calon presiden Partai Republik, Donald Trump menawarkan kebijakan ekonomi yang membatasi perdagangan antarnegara dengan cara meningkatkan tarif impor dan membatasi kuota impor. Kebijakan ini kemudian disebut kebijakan proteksionis yang diperkirakan akan memberikan dampak yang serius pada perekonomian di Cina dan negara-negara lain termasuk Indonesia 
yang menjadi mitra perdagangan negara tersebut. Selain itu, kebijakan lain yang akan berdampak besar bagi perekonomian Indonesia adalah kebijakan "The Fed" yang menaikkan tingkat suku bunga. Kombinasi kebijakan perdagangan dan fiskal tersebut diprediksi dapat meningkatkan tingkat inflasi maupun harga komoditas global sehingga secara otomatis akan berpengaruh pada kinerja perekonomian nasional (Liputan6.com, 2016).

Lain halnya dengan kandidat Partai Demokrat yaitu Hillary Clinton yang dinilai lebih kredibel dan menawarkan kebijakan-kebijakan yang lebih mendukung pelaku-pelaku bisnis. Hal tersebut berbanding terbalik dengan kandidat rivalnya yang membuat kebijakan yang bersifat kontroversial dan cenderung tidak berpihak pada sebagian besar pelaku bisnis. Sehingga pelaku bisnis cenderung lebih memilih sosok Clinton sebagai pemimpin Amerika Serikat. Kondisi tersebut tercermin pada indeks saham yang mulai meningkat sebagai imbas dari hasil polling terakhir yang menunjukkan Clinton masih memimpin (bbc.com, 2016).

Kedua kandidat calon presiden Amerika Serikat secara intensif terus mengeluarkan kebijakan-kebijakan yang akan diterapkan jika terpilih nantinya sebagai presiden. Kondisi tersebut menegaskan bahwa siapapun kandidat presiden yang terpilih nantinya akan memberikan pengaruh, baik pengaruh langsung maupun tidak langsung terhadap perekonomian Indonesia pada umumnya dan pasar modal khususnya. Oleh karena itu, perlu untuk dilakukan penelitian lebih lanjut guna melihat sejauh mana pasar modal Indonesia bereaksi terhadap 
Ni Made Ayu Windika Saraswati, Reaksi Pasar Modal Indonesia...

pengumuman hasil penghitungan suara dan pelantikan presiden di Amerika Serikat.

Penelitian mengenai reaksi pasar modal terhadap suatu peristiwa politik dalam negeri khususnya rangkaian peristiwa pemilihan umum telah banyak dilakukan. Penelitian yang dilakukan Lucinde (2012) memperoleh hasil return saham perusahaan yang terdaftar di Nairobi Securities Exchange meningkat selama pemilihan umum di Kenya. Nezerwe (2013) memperoleh hasil yang menyatakan bahwa pemilihan umum presiden di Mesir berpengaruh positif pada return saham Egyptian Stock Exchange. Penelitian Lie dkk. (2015) menyatakan bahwa terdapat perubahan yang signifikan pada harga saham LQ45 sebelum dan sesudah pemilihan umum presiden Indonesia tahun 2014. Hasil tersebut konsisten dengan penelitian sebelumnya, diantaranya Muturi (2014), Kabiru et al. (2015) dan Repousis (2016) yang memperoleh hasil bahwa terdapat perubahan yang signifikan pada abnormal returns saham sebelum dan setelah pengumuman hasil pemilihan umum. Berbeda dengan penelitian Oehler et al. (2013) yang menyatakan bahwa terdapat pengaruh negatif terhadap kemenangan kandidat partai demokrat pada return saham US-Stock Market secara keseluruhan.

Terdapat beberapa penelitian yang menjelaskan reaksi pasar modal dalam negeri terhadap rangkaian peristiwa pemilihan umum presiden Amerika Serikat diantaranya Hung (2013) menyatakan bahwa pemilihan umum presiden di Amerika Serikat berpengaruh pada Taiwanese Stock Market. Penelitian Hoe dan Nippani (2017) memperoleh hasil bahwa pemilihan umum presiden Amerika Serikat berpengaruh terhadap pasar modal di China. Gunaasih dkk. (2015) 
menyatakan bahwa Average Abnormal Return (AAR) dan Cumulative Average Abnormal Return (CAAR) menunjukkan nilai negatif dan signifikan pada indeks saham LQ45 selama periode acara pengumuman pemilihan presiden di Amerika Serikat pada 7 November 2012. Sama halnya dengan penelitian Nippani dan Arize (2005) yang dilakukan pada Canadian and Mexican Stock Markets. Berbeda dengan Sari dkk. (2017) yang menyatakan bahwa tidak ada perubahan pada ratarata abnormal return sebelum dan setelah peristiwa pilpres Amerika Serikat 2016.

Berdasarkan inkonsistensi hasil penelitian-penelitian tersebut, ditemukan research gap yang menjadi alasan untuk meneliti kembali reaksi pasar modal Indonesia terhadap rangkaian peristiwa pemilihan umum presiden Amerika Serikat. Penelitian ini mengacu pada penelitian Hung pada tahun 2013 yang menyatakan bahwa pemilihan presiden di Amerika Serikat berpengaruh pada Taiwanese Stock Market. Penelitian ini tidak sama dengan penelitian sebelumnya dalam hal objek penelitian yaitu indeks saham LQ45 dan studi peristiwa pada peristiwa pengumuman hasil penghitungan suara dan pelantikan presiden Amerika Serikat Tahun 2016. Penelitian ini dilakukan pada indeks saham LQ45 dengan alasan bahwa indeks ini terdiri dari 45 emiten dengan tingkat likuiditas dan kapitalisasi pasar yang tertinggi. Selain itu emiten yang termasuk ke dalam indeks LQ45 memiliki unit bisnis dengan jangkauan internasional atau Multinational Corporation (MNC) sehingga hasil pemilihan umum presiden Amerika Serikat akan memberikan dampak baik secara langsung maupun tidak langsung terhadap saham perusahaan tersebut. 
Ni Made Ayu Windika Saraswati, Reaksi Pasar Modal Indonesia...

Berdasarkan latar belakang yang sebelumya telah dipaparkan, maka rumusan masalah yang didapat yaitu sebagai berikut: apakah terdapat perbedaan abnormal return sebelum dan setelah peristiwa pengumuman hasil penghitungan suara pemilihan umum Presiden Amerika Serikat?; dan apakah terdapat perbedaan abnormal return sebelum dan setelah peristiwa pelantikan Presiden Amerika Serikat? Tujuan dari penelitian ini yaitu untuk member penjelasan mengenai perbedaan abnormal return sebelum dan setelah peristiwa pengumuman hasil penghitungan suara pemilihan umum serta abnormal return sebelum dan setelah peristiwa pelantikan Presiden Amerika Serikat.

Diharapkan penelitian ini nantinya dapat memberikan manfaat teoritis berupa bukti empiris mengenai studi peristiwa yang diimplementasikan untuk menjelaskan reaksi pasar modal Indonesia terhadap peristiwa politik dimana dalam hal ini adalah pergantian kepemimpinan terhadap kondisi perekonomian dan manfaat praktis berupa informasi kepada investor yang nantinya dapat digunakan sebagai dasar pengambilan.keputusan investasi yang berdasarkan pada isu global yaitu rangkaian peristiwa pemilihan umum presiden. Sehingga di masa mendatang investor mampu meminimalisir risiko kerugian yang mungkin dialami akibat kondisi ketidakpastian selama peristiwa pemilihan umum presiden.

Apabila harga sekuritas yang diperoleh di pasar modal secara menyeluruh mencerminkan seluruh informasi yang relevan maka pasar dapat dikatakan efisien. Jika informasi yang baru secara cepat terlihat pada harga sekuritas, maka semakin tinggi tingkat efisiensi pasar modal tersebut dan memperoleh abnormal return akan tidak mudah atau bahkan hampir tidak mungkin bagi investor 
(Ziobrowski et al, 2011). Fama dalam (Hartono, 2016:586), memaparkan bentukbentuk utama efisiensi pasar yang terdiri dari: 1) Efisiensi pasar bentuk lemah (weak form efficiency), dimana pasar dianggap berbentuk lemah apabila hargaharga sekuritas yang terdaftar di dalamnya mencerminkan secara penuh informasi masa lalu.; 2) Efisiensi pasar bentuk setengah kuat (semi strong form efficiency), dimana pasar dianggap efisien bentuk setengah kuat apabila harga-harga sekuritas yang terdaftar di dalamnya mencerminkan secara penuh informasi masa lalu dan juga semua informasi yang diumumkan.; dan 3) Efisiensi pasar bentuk kuat (strong form efficiency), dimana pasar dianggap efisien bentuk kuat apabila hargaharga sekuritas yang terdaftar di dalamnya mencerminkan informasi masa lalu, semua informasi yang diumumkan dan ditambah lagi dengan informasi yang private atau informasi yang tidak diumumkan.

Abnormal return merupakan hasil hitung dari selisih return sebenarnya (actual return) dengan return yang diharapkan (expected return) yang dapat terjadi sebelum diumumkannya informasi secara resmi atau adanya kebocoran informasi (leakage of information) setelah informasi secara resmi diumumkan (Samsul, 2006:275). Apabila return sebenarnya atau return yang didapatkan lebih besar dari return yang diharapkan atau return yang dihitung maka abnormal return akan bernilai positif, sedangkan apabila return sebenarnya atau return yang didapatkan lebih kecil dari return yang diharapkan atau dihitung maka abnormal return akan bernilai negatif (Rachmawati, 2005). Apabila dalam mengukur reaksi pasar menggunakan return tidak normal maka pengumuman yang memiliki kandungan informasi akan memberikan keuntungan (return) ke pasar, sebaliknya 
suatu pengumuman yang tidak mengandung informasi, tidak akan memberikan keuntungan ke pasar. Abnormal return diformulasikan sebagai berikut (Hartono, 2016:648):

$A R_{i, t}=R_{i, t}-E\left(R_{i, t}\right)$

Dimana:

$\mathrm{AR}_{\mathrm{i}, \mathrm{t}}=$ abnormal return kelompok saham dalam industri $\mathrm{i}$ periode $\mathrm{t}$

$\mathrm{R}_{\mathrm{i}, \mathrm{t}} \quad=$ actual return kelompok saham dalam industri $\mathrm{i}$ periode $\mathrm{t}$

$\mathrm{E}\left(\mathrm{R}_{\mathrm{i}, \mathrm{t}}\right)=$ expected return kelompok saham dalam industri i periode $\mathrm{t}$

Actual return adalah return yang terjadi pada waktu ke-t yang merupakan selisih harga sekarang relatif terhadap sebelumnya ( $\left.\mathrm{t}_{-1}\right)$. Secara matematis actual return dapat ditulis sebagai berikut:

$\mathrm{Ri}_{\mu_{\mathrm{t}}}=\frac{\mathrm{Pi}_{\mathrm{st}_{\mathrm{t}}}-\mathrm{Pi}_{s_{\mathrm{t}-1}}}{\mathrm{Pi}_{\mathrm{i}_{\mathrm{t}-1}}}$

Dimana:

$\mathrm{Ri}, \mathrm{t} \quad=$ actual return saham $\mathrm{i}$ pada hari $\mathrm{t}$

$\mathrm{Pi}_{, \mathrm{t}} \quad=$ harga penutupan saham $\mathrm{i}$ pada hari $\mathrm{t}$

$\mathrm{Pi}_{, \mathrm{t}-1} \quad=$ harga penutupan saham $\mathrm{i}$ pada hari $\mathrm{t}-1$

Menurut Brown \& Warner (1985) dalam Hartono (2016:648-660) menyebutkan ada tiga model dalam mengestimasi expected return yaitu meanadjusted model, market model, dan market-adjusted model. Mean-adjusted model atau model sesuaian rata-rata mengasumsikan nilai expected return adalah konstan dan nilainya sama dengan rata-rata actual return sebelumnya selama periode estimasi (estimation period). Umumnya periode estimasi (estimation 
period) merupakan periode sebelum periode peristiwa. Periode peristiwa (event period) sama dengan periode pengamatan atau jendela peristiwa (event window). Mean-adjusted model digambarkan dengan persamaan berikut:

$\mathrm{E}[\mathrm{Ri}, \mathrm{t}]=\frac{\sum_{\mathrm{j}=\mathrm{t} 1 \mathrm{1}}^{\mathrm{tn}} \mathrm{Ri} \mathrm{j}}{\mathrm{T}}$

Keterangan:

$\mathrm{E}\left[\mathrm{R}_{\mathrm{i}, \mathrm{t}}\right]=$ expected1return 1 sekuritas i pada periode peristiwa $\mathrm{t}$

$\mathrm{R}_{\mathrm{i}, \mathrm{t}} \quad=$ actual return sekuritas i pada periode peristiwa $\mathrm{t}$

$\mathrm{T} \quad=$ lamanya periode estimasi

Market model merupakan model perhitungan expected return dengan menggunakan teknik regresi. Terdapat dua tahap dalam menghitung expected return dengan menggunakan model ini, yaitu (1) membentuk model ekspektasi dengan menggunakan data realisasi selama periode estimasi dan (2) menggunakan model ekpektasi untuk mengestimasi expected return i di periode jendela. Market model dapat dibentuk menggunakan teknik regresi Ordinary Least Square (OLS) dengan persamaan berikut:

$R_{i, j}=\alpha_{1}+\beta i \cdot R_{M j}+e_{i, j}$

Keterangan:

$\mathrm{R}_{\mathrm{i}, \mathrm{j}} \quad=$ expected return sekuritas $\mathrm{i}$ pasa periode estimasi $\mathrm{j}$

$\alpha_{1} \quad=$ intersep untuk sekuritas $\mathrm{i}$

$\beta_{\mathrm{i}} \quad=$ koefisien slope yang merupakan beta dari sekuritas $\mathrm{i}$

$\mathrm{R}_{\mathrm{Mj}} \quad=$ return indeks pasar pada periode estimasi $\mathrm{j}$

$\mathrm{e}_{\mathrm{i}, \mathrm{j}} \quad=$ kesalahan residu sekuritas $\mathrm{i}$ pada periode estimasi $\mathrm{j}$ 
Market-adjusted model atau model sesuaian-pasar berasumsi bahwa return indeks pasar pada saat tersebut merupakan penduga terbaik untuk mengestimasi return suatu sekuritas. Perbedaan model ini yaitu tidak perlu menggunakan periode estimasi untuk membentuk model estimasi model ini, karena return indeks pasar adalah sama dengan return sekuritas yang diestimasi. Marketadjusted model digambarkan dengan persamaan berikut:

$\mathrm{E}\left[\mathrm{R}_{\mathrm{i}, \mathrm{t}}\right]=\mathrm{R}_{\mathrm{M}, \mathrm{t}}$

Keterangan:

$\mathrm{E}\left[\mathrm{R}_{\mathrm{i}, \mathrm{t}}\right]=$ expected return sekuritas i pada periode peristiwa $\mathrm{t}$

$\mathrm{R}_{\mathrm{M}, \mathrm{t}} \quad=$ return indeks pasar pada periode peristiwa $\mathrm{t}$

Dimana:

$\mathrm{R}_{\mathrm{M}, \mathrm{t}}=\frac{\mathrm{ILQ} 45_{\mathrm{t}}-\mathrm{ILQ}_{4} 5_{\mathrm{t}-1}}{\mathrm{ILQ} 45_{\mathrm{t}-1}}$

Dimana:

ILQ45t $=\frac{\text { Nilai Pasar }}{\text { Nilai Dasar }} \times 100$

Keterangan:

ILQ45t = harga indeks pasar pada hari $\mathrm{t}$

Nilai Pasar = nilai pasar agregat (nilai total saham yang beredar di Bursa Efek Indonesia) pada hari t

Nilai Dasar = nilai dasar agregat (nilai total dari saham yang beredar saat pertama kali indeks LQ45 diluncurkan) 
Studi untuk menguji reaksi pasar terhadap suatu event (peristiwa) yang informasinya dipublikasikan sebagai suatu pengumuman disebut studi peristiwa (Hartono, 2016:623). Reaksi pasar dicerminkan oleh perubahan harga dari sekuritas yang bersangkutan. Menilai perbedaan harga atau menghitung abnormal return merupakan cara untuk mengukur reaksi pasar. Abnormal return akan timbul pada peristiwa yang memuat informasi, sebaliknya abnormal return tidak akan timbul pada peristiwa yang tidak memuat informasi. Suatu pengumuman yang memiliki informasi buruk biasanya akan direspon negatif oleh pasar dan pengumuman yang memiliki informasi baik akan direspon positif oleh pasar.

Studi peristiwa pada umumnya berkaitan dengan seberapa cepat suatu informasi masuk ke pasar yang tercermin pada harga saham (Tandelilin, 2010:239). Pengujian yang melibatkan kecepatan reaksi pasar dalam menyerap informasi yang diberikan suatu pengumuman adalah pengujian efisiensi pasar secara informasi (informationally efficient market) dalam bentuk setengah kuat.

Peristiwa politik khususnya rangkaian peristiwa pemilihan umum presiden sangat berpengaruh terhadap kegiatan perdagangan di pasar modal karena peristiwa politik berkaitan erat dengan kestabilan perekonomian. Peristiwa politik kerap kali menjadi pemicu fluktuasi harga saham di pasar modal seluruh dunia khususnya di Indonesia, dimana para investornya cenderung melakukan investasi jangka pendek. Semakin penting peran pasar modal dalam kegiatan ekonomi, maka semakin sensitif terhadap berbagai peristiwa disekitarnya, baik itu berkaitan atau tidak berkaitan secara langsung dengan isu ekonomi (Nurhaeni, 2009). 
Reaksi pasar diukur dengan menggunakan abnormal return. Abnormal return dapat terjadi karena adanya suasana politik yang tidak menentu. Beberapa penelitian telah dilakukan untuk menganalisis reaksi pasar modal dalam negeri terhadap rangkaian peristiwa pemilihan umum presiden Amerika Serikat diantaranya Hung (2013) menyelidiki dampak internasional dari pemilihan Presiden di Amerika Serikat pada Taiwanese Stock Market. Hasil penelitian menunjukkan bahwa putaran pemilihan Presiden di Amerika Serikat berpengaruh terhadap Taiwanese Stock Market. Hasil tersebut konsisten dengan penelitian Hoe dan Nippani (2017) yang menyatakan bahwa pemilihan umum presiden Amerika Serikat berpengaruh terhadap pasar modal di China.

Penelitian Gunaasih dkk. (2015) menyatakan bahwa Average Abnormal Return (AAR) dan Cumulative Average Abnormal Return (CAAR) menunjukkan nilai negatif dan signifikan pada indeks saham LQ45 selama periode acara pengumuman pemilihan presiden di Amerika Serikat pada 7 November 2012. Hasil yang sama diperoleh oleh Nippani dan Arize (2005) yang menyatakan pemilihan umum presiden Amerika Serikat memberikan dampak negatif pada Canadian and Mexican Stock Markets.

Berdasarkan paparan di atas, hipotesis penelitian ini dikembangkan sebagai berikut:

$\mathrm{H}_{1}$ : Terdapat perbedaan abnormal return sebelum dan setelah peristiwa pengumuman hasil penghitungan suara pemilihan umum presiden Amerika Serikat. 
$\mathrm{H}_{2}$ : Terdapat perbedaan abnormal return sebelum dan setelah peristiwa pelantikan presiden Amerika Serikat.

\section{METODE PENELITIAN}

Lokasi penelitian yaitu pada perusahaan-perusahaan yang terdaftar dalam indeks LQ45 Bursa Efek Indonesia yang diakses melalui website www.idx.co.id. Reaksi pasar modal Indonesia terhadap peristiwa pengumuman hasil penghitungan suara dan pelantikan presiden Amerika Serikat pada perusahaan yang termasuk dalam Indeks LQ45 digunakan sebagai objek penelitian. Penelitian ini menggunakan data kuantitatif berupa data harga saham-saham yang terdaftar di indeks LQ45 Bursa Efek Indonesia selama periode penelitian. Sumber data yang digunakan adalah data sekunder.

Metode pengumpulan data yang digunakan adalah metode observasi non partisipan yaitu observasi yang dilakukan tanpa melibatkan diri dan hanya sebagai pengamat independen. Data dikumpulkan dengan cara mengamati serta mencatat, dan mempelajari uraian-uraian dari buku, karya ilmiah berupa jurnal, tesis, skripsi, surat kabar, internet, dan sebagainya yang berkaitan dengan topik penelitian.

Tanggal terjadinya masing-masing peristiwa (event date) yaitu peristiwa pengumuman hasil penghitungan suara pemilihan umum Presiden Amerika Serikat pada tanggal 5 Januari 2017 dan peristiwa pelantikan Presiden Amerika Serikat pada tanggal 20 Januari 2017 yang digunakan sebagai hari ke-0. Periode jendela (event window) yaitu selama 7 hari bursa (hari kerja), terdiri dari t-3 
(prevent, 3 hari sebelum peristiwa), $\mathrm{t}_{0}$ (event date, hari terjadinya peristiwa), dan $\mathrm{t}_{+3}$ (point event, 3 hari setelah peristiwa). Periode peristiwa yang digunakan dalam penelitian ini disajikan dalam Gambar 1.

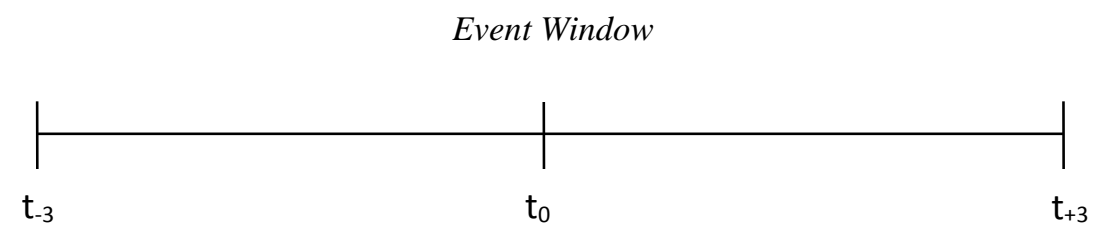

Gambar 1. Periode Peristiwa (Event Window)

Variabel yang diidentifikasi dalam penelitian ini adalah abnormal return. Untuk mencari abnormal return maka diperlukan perhitungan sebagai ${ }^{1}$ berikut:

$$
A R_{i, t}=R_{i, t}-E\left(R_{i, t}\right)
$$

Keterangan:

$\mathrm{AR}_{\mathrm{i}, \mathrm{t}}=$ abnormal return kelompok saham dalam industri i periode $\mathrm{t}$

$\mathrm{R}_{\mathrm{i}, \mathrm{t}} \quad=$ actual return kelompok saham dalam industri $\mathrm{i}$ periode $\mathrm{t}$

$\mathrm{E}\left(\mathrm{R}_{\mathrm{i}, \mathrm{t}}\right)=$ expected return kelompok saham dalam industri i periode $\mathrm{t}$

Sebelum mencari abnormal return diperlukan perhitungan untuk mencari actual return dan expected return terlebih dahulu. Actual return dihitung dengan rumus:

$$
\mathrm{Ri}_{y_{\mathrm{t}}}=\frac{\mathrm{Pi}_{\mathrm{st}_{\mathrm{t}}}-\mathrm{Pi}_{\mathrm{s}_{\mathrm{t}-1}}}{\mathrm{Pi}_{\mathrm{s}_{\mathrm{t}-1}}}
$$

Keterangan:

$\mathrm{Ri}, \mathrm{t}=$ actual return saham $\mathrm{i}$ pada hari $\mathrm{t}$

$\mathrm{Pi}_{, \mathrm{t}} \quad=$ harga penutupan saham i pada hari $\mathrm{t}$

$\mathrm{Pi}_{\mathrm{t}-1} \quad=$ harga penutupan saham i pada hari $\mathrm{t}-1$ 
Expected return dihitung dengan menggunakan model sesuaian pasar (market adjusted model).

$\mathrm{E}\left[\mathrm{R}_{\mathrm{i}, \mathrm{t}}\right]=\mathrm{R}_{\mathrm{M}, \mathrm{t}}$

Keterangan:

$\mathrm{E}\left[\mathrm{R}_{\mathrm{i}, \mathrm{t}}\right]=$ expected return sekuritas i pada periode peristiwa $\mathrm{t}$

$\mathrm{R}_{\mathrm{M}, \mathrm{t}} \quad=$ return indeks pasar pada periode peristiwa $\mathrm{t}$

Dimana:

$\mathrm{R}_{\mathrm{M}, \mathrm{t}}=\frac{\mathrm{ILQ} 45_{\mathrm{t}}-\mathrm{ILQ} 45_{\mathrm{t}-1}}{\mathrm{ILQ} 45_{\mathrm{t}-1}}$

Keterangan:

$\mathrm{R}_{\mathrm{M}, \mathrm{t}} \quad=$ return pasar pada hari $\mathrm{t}$

ILQ45t = harga indeks pasar pada hari $\mathrm{t}$

ILQ45 $\mathrm{t}-1=$ harga indeks pasar pada hari $\mathrm{t}-1$

Dimana:

ILQ45t $=\frac{\text { Nilai Pasar }}{\text { Nilai Dasar }} x 100$

Keterangan:

ILQ45 $\quad=$ harga indeks pasar pada hari $\mathrm{t}$

Nilai Pasar = nilai pasar agregat (nilai total saham yang beredar di Bursa Efek Indonesia) pada hari t

Nilai Dasar = nilai dasar agregat (nilai total dari saham yang beredar saat pertama kali indeks LQ45 diluncurkan) 
Perusahaan-perusahaan yang terdaftar di indeks LQ45 Bursa Efek Indonesia selama periode penelitian digunakan sebagai populasi penelitian. Metode pemilihan sampel dilakukan dengan cara non probability sampling, yaitu dengan menggunakan pendekatan purposive sampling. Adapun kriteria untuk memperoleh sampel yaitu perusahaan LQ45 yang mempublikasikan data harga saham selama periode penelitian dan perusahaan yang benar-benar bersih dari confounding effect yang ditimbulkan oleh perusahaan. Confounding effect yang dimaksud seperti tidak melakukan stock split, pengumuman dividen, merger, dan right issues. Sehingga sampel yang nantinya terpilih benar-benar menunjukkan return saham perusahaan.

Pengujian tingkat signifikansi abnormal return selama periode peristiwa menggunakan uji parametrik paired sample t-test. Langkah pengujian hipotesis adalah sebagai berikut: 1) Merumuskan hipotesis; 2) Menentukan abnormal return disekitar peristiwa; 3) Menentukan derajat kepercayaan, yaitu 95\% dengan tingkat signifikansi alpha 5\%; dan 4) Menentukan kriteria pengujian hipotesis. Jika nilai probabilitas yang didapat lebih besar dari 5\% maka $\mathrm{H}_{0}$ diterima. Hal ini menunjukkan bahwa tidak terdapat perbedaan yang signifikan. Jika probabilitas lebih kecil dari 5\% maka $\mathrm{H}_{0}$ ditolak. Hal ini menunjukkan bahwa terdapat perbedaan yang signifikan.

\section{HASIL DAN PEMBAHASAN}

Penelitian ini membahas perusahaan LQ45 periode Agustus 2016 yang kemudian dipilih sampel menggunakan pendekatan purposive sampling sesuai 
kriteria yang telah dijelaskan sebelumnya. Sehingga mendapatkan sampel yaitu seluruh perusahaan yang masuk dalam indeks LQ45 periode Agustus 2016 yang berjumlah 45 perusahaan.

\section{Tabel 1.}

Analisis Statistik Deskriptif

Abnormal Return pada Peristiwa Pengumuman Hasil Penghitungan Suara

\begin{tabular}{lccccc}
\hline & N & Minimum & Maximum & Mean & Std. Deviation \\
\hline Sebelum & 45 & -0.016508802 & 0.030630614 & 0.00215535485 & 0.009180390162 \\
Setelah & 45 & -0.027783757 & 0.016868286 & -0.00208125974 & 0.008848789167 \\
Valid $N$ & 45 & & & & \\
(listwise) & & & & & \\
\hline
\end{tabular}

Sumber: Data Diolah, 2017

Tabel 1. menunjukkan nilai minimum, maksimum, mean dan standar deviasi abnormal return pada peristiwa pengumuman hasil penghitungan suara pemilihan umum presiden Amerika Serikat. Sebelum peristiwa, nilai minimum sebesar 0.016508802 diperoleh oleh perusahaan Vale Indonesia Tbk. dan nilai maksimum sebesar 0.030630614 diperoleh oleh perusahaan Alam Sutera Reality Tbk. Mean abnormal return sebelum peristiwa bernilai positif sebesar 0.00215535485 dan standar deviasi sebesar 0.009180390162 .

Setelah peristiwa, nilai minimum sebesar -0.027783757 diperoleh oleh perusahaan Matahari Putra Prima Tbk. dan nilai maksimum sebesar 0.016868286 diperoleh oleh perusahaan AKR Corporindo Tbk. Mean abnormal return setelah peristiwa bernilai negatif sebesar -0.00208125974 dan standar deviasi sebesar 0.008848789167 .

Abnormal return tertinggi diperoleh sebelum terjadinya peristiwa dan abnormal return terendah diperoleh setelah terjadinya peristiwa. Mean abnormal return bernilai positif diperoleh sebelum terjadinya peristiwa sebaliknya mean abnormal return yang negatif diperoleh setelah terjadinya peristiwa. Terjadinya 
perbedaan nilai mean abnormal return pada periode pengamatan sebelum dan setelah peristiwa pengumuman hasil penghitungan suara pemilihan umum presiden Amerika Serikat secara deskriptif menunjukkan bahwa keadaan pada saat sebelum dan setelah peristiwa tersebut mengandung informasi yang cukup untuk membuat pasar bereaksi.

Tabel 2.

Analisis Statistik Deskriptif Abnormal Return pada Peristiwa Pelantikan Presiden

\begin{tabular}{lccccc}
\hline & N & Minimum & Maximum & Mean & Std. Deviation \\
\hline Sebelum & 45 & -0.018745971 & 0.030881379 & 0.00206797740 & 0.010297078171 \\
Setelah & 45 & -0.038458823 & 0.019920379 & -0.00331819687 & 0.011314726742 \\
Valid N & 45 & & & & \\
(listwise) & & & & & \\
\hline \multicolumn{4}{l}{ Sumber: } \\
Data Diolah 2017
\end{tabular}

Sumber: Data Diolah, 2017

Tabel 2. menjelaskan nilai minimum, maksimum, mean dan standar deviasi abnormal return pada peristiwa pelantikan presiden Amerika Serikat. Sebelum peristiwa, nilai minimum sebesar -0.018745971 diperoleh oleh perusahaan Hanson International Tbk. dan nilai maksimum sebesar 0.030881379 diperoleh oleh perusahaan Alam Sutera Reality Tbk. Mean abnormal return sebelum peristiwa bernilai positif sebesar 0.00206797740 dan standar deviasi sebesar 0.010297078171 .

Setelah peristiwa, nilai minimum sebesar -0.038458823 diperoleh oleh perusahaan Matahari Putra Prima Tbk. dan nilai maksimum6sebesar 0.019920379 diperoleh oleh perusahaan Elnusa Tbk. Mean abnormal return setelah peristiwa bernilai negatif sebesar -0.00331819687 dan standar deviasi sebesar 0.011314726742 .

Abnormal return tertinggi diperoleh sebelum terjadinya peristiwa dan abnormal return terendah diperoleh setelah terjadinya peristiwa. Mean abnormal 
return bernilai positif diperoleh sebelum terjadinya peristiwa sebaliknya mean abnormal return yang negatif diperoleh setelah terjadinya peristiwa. Terjadinya perbedaan hasil mean abnormal return pada periode pengamatan sebelum dan setelah peristiwa pelantikan presiden Amerika Serikat secara deskriptif menunjukkan bahwa keadaan pada saat sebelum dan setelah peristiwa tersebut mengandung informasi yang cukup untuk membuat pasar bereaksi.

Tabel 3.

Hasil Uji Normalitas

Abnormal Return pada Peristiwa Pengumuman Hasil Penghitungan Suara One-Sample Kolmogorov-Smirnov Test

\begin{tabular}{llrr}
\hline & & \multicolumn{1}{c}{ Sebelum } & \multicolumn{1}{c}{ Setelah } \\
\hline $\mathrm{N}$ & & 45 & 45 \\
Normal Parameters & a,b & 0.00215535485 & -0.00208125974 \\
& Mean & 0.009180390162 & 0.008848789167 \\
Most Extreme Differences & Std. Deviation & 0.178 & 0.134 \\
& Absolute & 0.178 & 0.087 \\
& Positive & -0.124 & -0.134 \\
& Negative & 1.194 & 0.896 \\
Kolmogorov-Smirnov Z & & 0.115 & 0.399 \\
Asymp. Sig. (2-tailed) & & &
\end{tabular}

Tabel 4.

Hasil Uji Normalitas

Abnormal Return pada Peristiwa Pelantikan Presiden One-Sample Kolmogorov-Smirnov Test

\begin{tabular}{llrr}
\hline & & \multicolumn{1}{c}{ Sebelum } & \multicolumn{1}{c}{ Setelah } \\
\hline $\mathrm{N}$ & & 45 & 45 \\
Normal Parameters & Mean & 0.00206797740 & -0.00331819687 \\
& Std. Deviation & 0.010297078171 & 0.011314726742 \\
Most Extreme Differences & Absolute & 0.180 & 0.143 \\
& Positive & 0.180 & 0.105 \\
& Negative & -0.131 & -0.143 \\
Kolmogorov-Smirnov Z & & 1.211 & 0.962 \\
Asymp. Sig. (2-tailed) & & 0.107 & 0.313 \\
\hline Sumber: Data Diolah, 2017 & & &
\end{tabular}

Hasil uji normalitas abnormal return untuk peristiwa pertama yaitu sebelum dan setelah peristiwa pengumuman hasil penghitungan suara pemilihan umum presiden Amerika Serikat dan peristiwa kedua yaitu sebelum dan setelah peristiwa pelantikan presiden Amerika Serikat menunjukkan hasil di atas 0,05 sehingga 
disimpulkan bahwa data berdistribusi normal. Hasil pengujian ini dijadikan dasar untuk pengujian hipotesis dengan menggunakan uji parametrik paired sample $t$ test.

Reaksi pasar diproksikan dengan abnormal return. Apabila terdapat perbedaan abnormal return sebelum dan setelah terjadinya suatu peristiwa maka pasar dikatakan bereaksi terhadap peristiwa tersebut.

Tabel 5.

Uji Paired Sample t-test

Peristiwa Pengumuman Hasil Penghitungan Suara

\begin{tabular}{|c|c|c|c|c|c|c|c|c|c|}
\hline & & \multicolumn{5}{|c|}{ Paired Differences } & \multirow{3}{*}{$\mathbf{t}$} & \multirow{3}{*}{ df } & \multirow{3}{*}{$\begin{array}{l}\text { Sig. (2- } \\
\text { tailed) }\end{array}$} \\
\hline & & \multirow[t]{2}{*}{ Mean } & \multirow[t]{2}{*}{$\begin{array}{c}\text { Std. } \\
\text { Deviation }\end{array}$} & \multirow[t]{2}{*}{$\begin{array}{l}\text { Std. Error } \\
\text { Mean }\end{array}$} & \multicolumn{2}{|c|}{$\begin{array}{l}\text { 95\% Confidence } \\
\text { Interval of the } \\
\text { Difference }\end{array}$} & & & \\
\hline & & & & & Lower & Upper & & & \\
\hline Pair & $\begin{array}{c}\text { Sebelum } \\
- \\
\text { Setelah }\end{array}$ & $\begin{array}{c}0.004236 \\
614594\end{array}$ & $\begin{array}{c}0.01275600 \\
9873\end{array}$ & $\begin{array}{c}0.0019015 \\
53680\end{array}$ & $\begin{array}{c}0.000404 \\
284967\end{array}$ & $\begin{array}{l}0.00806 \\
8944222\end{array}$ & 2.228 & 44 & 0.031 \\
\hline
\end{tabular}

Sumber: Data Diolah, 2017

Tabel 5. menampilkan hasil pengujian paired sample t-test abnormal return sebelum dan setelah peristiwa pengumuman hasil penghitungan suara pemilihan umum presiden Amerika Serikat. Berdasarkan tabel 5. didapat sig. (2-tailed) $0,031<0,050$ sehingga disimpulkan bahwa $\mathrm{H} 1$ diterima karena terdapat perbedaan abnormal return sebelum dan setelah peristiwa pengumuman hasil perhitungan suara pemilihan umum presiden Amerika Serikat. Berdasarkan hasil uji paired sample t-test abnormal return perusahaan-perusahaan LQ45 di BEI sebelum dan setelah peristiwa pengumuman hasil penghitungan suara pemilihan umum presiden Amerika Serikat maka dapat dikatakan bahwa pasar berbentuk setengah kuat secara informasi. 
Tabel 6.

Uji Paired Sample t-test

Peristiwa Pelantikan Presiden

\begin{tabular}{|c|c|c|c|c|c|c|c|c|c|}
\hline & & \multicolumn{5}{|c|}{ Paired Differences } & \multirow{3}{*}{$\mathbf{t}$} & \multirow{3}{*}{ Df } & \multirow{3}{*}{$\begin{array}{l}\text { Sig. (2- } \\
\text { tailed) }\end{array}$} \\
\hline & & \multirow[t]{2}{*}{ Mean } & \multirow[t]{2}{*}{$\begin{array}{c}\text { Std. } \\
\text { Deviation }\end{array}$} & \multirow[t]{2}{*}{$\begin{array}{l}\text { Std. Error } \\
\text { Mean }\end{array}$} & \multicolumn{2}{|c|}{$\begin{array}{l}\text { 95\% Confidence } \\
\text { Interval of the } \\
\text { Difference }\end{array}$} & & & \\
\hline & & & & & Lower & Upper & & & \\
\hline Pair & $\begin{array}{c}\text { Sebelum } \\
- \\
\text { Setelah }\end{array}$ & $\begin{array}{c}0.005386 \\
174267\end{array}$ & $\begin{array}{c}0.01535187 \\
8716\end{array}$ & $\begin{array}{c}0.0022885 \\
22959\end{array}$ & $\begin{array}{c}0.000773 \\
959301\end{array}$ & $\begin{array}{l}0.00999 \\
8389232\end{array}$ & 2.354 & 44 & 0.023 \\
\hline
\end{tabular}

Sumber: Data Diolah, 2017

Tabel 6. menampilkan hasil pengujian paired sample t-test abnormal return sebelum dan setelah peristiwa pelantikan presiden Amerika Serikat. Berdasarkan tabel 6. didapat sig. (2-tailed) $0,023<0,050$ sehingga disimpulkan bahwa $\mathrm{H} 2$ diterima karena terdapat perbedaan abnormal return sebelum dan setelah peristiwa pelantikan presiden Amerika Serikat artinya terdapat reaksi pasar di sekitar peristiwa pelantikan presiden Amerika Serikat. Pasar bereaksi ditunjukkan oleh investor yang sensitif dalam menyerap dan merespon informasi dari peristiwa tersebut. Maka dari itu dapat dikatakan bahwa pasar berbentuk setengah kuat secara informasi.

\section{SIMPULAN DAN SARAN}

Berdasarkan hasil analisis dan pembahasan yang telah dijelaskan sebelumnya, maka simpulan dari penelitian ini adalah: terdapat perbedaan abnormal return sebelum dan setelah peristiwa pengumuman hasil penghitungan suara pemilihan umum Presiden Amerika Serikat, hal ini menunjukkan bahwa terdapat reaksi pasar di sekitar peristiwa pengumuman hasil penghitungan suara pemilihan umum presiden Amerika Serikat.; dan terdapat perbedaan abnormal return sebelum dan setelah peristiwa pelantikan Presiden Amerika Serikat yang 
Ni Made Ayu Windika Saraswati, Reaksi Pasar Modal Indonesia...

terpilih, hal ini menunjukkan bahwa terdapat reaksi pasar di sekitar peristiwa pelantikan Presiden Amerika Serikat.

Peneliti menyarankan investor di Indonesia agar lebih berhati-hati dalam membuat keputusan untuk berinvestasi terkait dengan fenomena-fenomena yang terjadi selama pemilihan umum presiden Amerika Serikat. Bagi penelitian selanjutnya diharapkan tidak hanya menggunakan parameter abnormal return untuk menguji reaksi pasar tetapi juga menggunakan trading volume activity. Disarankan pula untuk menambahkan analisis antar sektor atau menggunakan jenis perusahaan yang terdaftar dalam indeks harga saham gabungan (IHSG) sebagai sampel sehingga hasilnya lebih akurat, menggunakan model estimasi yang berbeda dalam menghitung expected return dan menambah jumlah pengamatan yang lebih panjang. Hal tersebut bertujuan agar hasil penelitian semakin menggambarkan reaksi pasar atas suatu peristiwa.

\section{IMPLIKASI HASIL PENELITIAN}

Hasil penelitian ini memberikan implikasi bahwa tidak semua informasi yang diperoleh di pasar modal merupakan informasi yang relevan untuk dijadikan sebagai dasar pengambilan keputusan, maka dari itu para investor harus cermat dalam menganalisis dan memilah informasi-informasi tersebut, sehingga diharapkan investor tidak tergesa-gesa untuk bertindak dalam aktivitas transaksi saham dan lebih berpikir rasional dalam mengambil keputusan investasi. Selain itu, peneliti juga menuntut para investor agar lebih sensitif jika terjadi peristiwa atau pengumuman yang dengan langsung ataupun tidak langsung dapat memberi 
pengaruh pada harga saham. Selama terjadi peristiwa, para investor juga diharapkan untuk selalu berhati-hati dalam memperkirakan relevansi antara peristiwa dengan pergerakan harga saham di pasar modal.

\section{REFERENSI}

Ananto, Dedy. 2014. Pengaruh Pemilu Legislatif Terhadap Abnormal Return dan Trading Volume Activity Saham di Jakarta Islamic Index (Studi Kasus Pada Peristiwa Pemilu Legislatif 09 April 2014). Skripsi. Program Studi Keuangan Islam, Universitas Islam Negeri Sunan Kalijaga.

Gunaasih, Sang Ayu Putu Piastini dan Irfan Nursasmito. 2015. The Evaluation of Non-Economic Events towards the LQ-45 Index in Indonesia Stock Exchange by Using Event Study Method. Society of Interdisciplinary Business Research, 4(2): 106-120.

Hartono, Jogiyanto. 2010. Studi Peristiwa: Menguji Reaksi Pasar Modal Akibat Suatu Peristiwa, Edisi Pertama. Yogyakarta: BPFE.

Hartono, Jogiyanto. 2016. Teori Portofolio dan Analisis Investasi, Edisi Kesepuluh. Yogyakarta: BPFE.

Hung, Ling Chung. 2013. U.S. Presidential Elections and the Taiwanese Stock Market. Journal Issues \& Studies, 49(1): 71-97.

Hoe, SingRu dan Srinivas Nippani. 2017. 2016 U.S. President Election and Stock Markets in China. International Journal of economics and Finance, 9(7): 32-38.

http://bisnis.liputan6.com/read/2611902/mengintip-strategi-ekonomi-hillaryclinton-vs-donald-trump (diunduh tanggal 10 April 2017)

https://finance.yahoo.com (diunduh tanggal 27 Agustus 2017)

http://www.bbc.com/indonesia/dunia-38648104 (diunduh tanggal 10 April 2017)

http://www.idx.co.id/Portals/0/StaticData/Publication/LQ45/20161010_IDX-

LQ45-August-2016.pdf (diunduh tanggal 8 Mei 2017)

http://www.duniainvestasi.com/bei/ (diunduh tanggal 2 Oktober 2017) 
Kabiru, James Ndungu, Duncan Elly Ochieng, dan Hellen Wairimu Kinyua. 2015. The Effect of General Elections on Stock Returns at The Nairobi Securities Exchange. European Scientific Journal, 11(28): 435-460.

Laksitafresti, Astri. 2012. Pengaruh Opini Wajar Tanpa Pengecualian dengan Paragraf Penjelas (WTP-PP) dan Opini Wajar dengan Pengecualian Terhadap Harga Saham dan Volume Perdagangan Saham (Studi Empiris Pada Perusahaan Manufaktur yang Terdaftar di Bursa Efek Indonesia Periode 2004-2010). Skripsi. Fakultas Ekonomi dan Bisnis, Universitas Diponegoro.

Lie, Dave Danie, Sifrid.S. Pangemanan., dan Johan Tumiwa. 2015. Comparative Of Stock Price Before And After Indonesian Presidential Election In 2014 Of Lq-45 Stock Listed On IDX. Jurnal EMBA, 3(3): 533-543.

Muturi, Chege Robert. 2014. Stock Market Reaction to Presidential Election Results Announcement in Kenya: A Look At 1997 - 2013 Elections. Thesis. Degree of Master of Business Administration, University of Nairobi.

Ningsih, Ervina Ratna dan Dwi Cahyaningdyah. 2014. Reaksi Pasar Modal Indonesia Terhadap Pengumunan Kenaikan Harga BBM 22 Juni 2013. Management Analysis Journal, 1(3): 1-5.

Nippani, Srinivas dan Augustine C. Arize. 2005. U.S. Presidential Election Impact on Canadian and Mexican Stock Markets. Journal of Economics and Finance, 29(2): 271-279.

Nurhaeni, Nunung. 2009. Dampak Pemilihan Umum Legislatif Indonesia Tahun 2009 Terhadap Abnormal Return dan Aktivitas Volume Perdagangan Saham di BEI (Uji Kasus pada Saham yang Terdaftar dalam Kelompok Perusahaan LQ45). Tesis. Program Studi Magister Manajemen, Universitas Diponegoro.

Oehler, Andreas., Thomas J.Walker, dan Stefan Wendt. 2013. Effects of Election Results on Stock Price Performance: Evidence From 1980 to 2008. Managerial Finance, 39(8): 714-736.

Repousis, Spyridon. 2016. Stocks' Prices Manipulation Around National Elections?: An Event Study for The Case of Greek Banking Sector. Journal of Financial Crime. 23(2): 248-25.

Samsul, Mohamad. 2006. Pasar Modal dan Manajemen Portofolio. Jakarta: Erlangga. 
Sari, Tila Permata, Ayu Purnamawati, dan Trisna Herawati. 2017. Analisis Komparatif Saham LQ45 Sebelum dan Sesudah Pilpres Amerika Serikat 2016. e-Journal S1 Ak Universitas Pendidikan Ganesha, 7(1): 1-10.

Suryawijaya, Marwan Asri dan Faizal Arief Setiawan. 1998. Reaksi Pasar Modal Indonesia Terhadap Peristiwa Politik Dalam Negeri (Event Study Pada Peristiwa 27 Juli 1996). Jurnal Kelola, 18(7): 137-153.

Tandelilin, Eduardus. 2010. Portofolio dan Investasi: Teori dan Aplikasi, Edisi Pertama. Jogjakarta: Kanisius.

Trisnawati, Dian dan Ayu Diantini. 2013. Analisis Pengaruh Reshuffle Kabinet Indonesia Bersatu II Terhadap Harga Saham LQ45 di Bursa Efek Indonesia. Jurnal Manajemen Universitas Udayana, 2(10): 1279-1292.

Ziobrowski A., Boyd, J, W., Cheng, P., and Ziobrowski, B, J. 2011. Abnormal Returns From the Common Stock Investments of Members of the U.S. House of Representatives Stock Market. Journal Bussiness and Politics, 13(4): 1-22. 